\title{
HUMAN MUMMIFICATION PRACTICES AMONG THE IBALOY OF KABAYAN, NORTH LUZON, THE PHILIPPINES
}

\author{
Ronald G. Beckett ${ }^{1}$, Gerald J. Conlogue ${ }^{1}$, \\ Orlando V. Abinion ${ }^{2}$, Analyn Salvador-Amores 3 , \\ DARIO PIOMBINO-MASCALi ${ }^{4,5}$ \\ ${ }^{1}$ Bioanthropology Research Institute, Quinnipiac University, Hamden, USA \\ ${ }^{2}$ National Museum of the Philippines, Manila, the Philippines \\ ${ }^{3}$ Department of Social Anthropology, University of the Philippines Baguio, \\ Baguio City, the Philippines \\ ${ }^{4}$ Department of Cultural Heritage and of Sicilian Identity, Palermo, Italy \\ ${ }^{5}$ Department of Anatomy, Histology and Anthropology, Vilnius University, \\ Vilnius, Lithuania
}

\begin{abstract}
The province of Benguet, situated in North Luzon, the Philippines, holds a large number of ancient mummified remains, mostly located within the municipality of Kabayan. Such bodies are mainly associated to the Ibaloy one of the indigenous groups collectively known as Igorot - and are stored in natural rockshelters or caves carved into the stone, inside wooden coffins often obtained from hollowed pine tree segments. Recent inspections of some of these corpses, carried out in 2002 and 2012, indicated the nature of their mummification process as well as some details regarding their bioanthropological features. Although very little information was initially available on these bodies, the authors have gathered significant oral information on funerary rituals and attitudes towards the ancestors via interviews with the local elders, as well as data on the vegetal materials employed and the practice of tattooing. This paper is the first critical evaluation of these mummies and demonstrates the uniqueness and preciousness of this biocultural heritage now in danger.
\end{abstract}

Keywords: bioarchaeology; mummies; mummification; Ibaloy; Kabayan 


\section{INTRODUCTION}

The province of Benguet, situated in North Luzon, the Philippines, holds a large number of ancient mummified remains, mostly located within the municipality of Kabayan [17]. The broader Kabayan region is a rugged mountainous terrain and consists of thirteen baranggays, or villages, where the Ibaloy culture has practised terraced farming for centuries (Fig. 1). Their crops include carrots, potatoes, cabbages, beans, tomatoes, and upland rice [2,3]. The Ibaloy hold the tradition of peshit, or prestige rites, whereby one enhances their social position through a series of ceremonies by butchering pigs and other animals and sharing them with kin and neighbours [6, 7]. The Ibaloy are part of an indigenous culture collectively known as the Igorot. Reportedly, the Ibaloy have practised a form of mummification for centuries spanning from the 1700s through the 1900s [17]. Other sources suggest that the mummification practice began long before this period $[14,15]$.

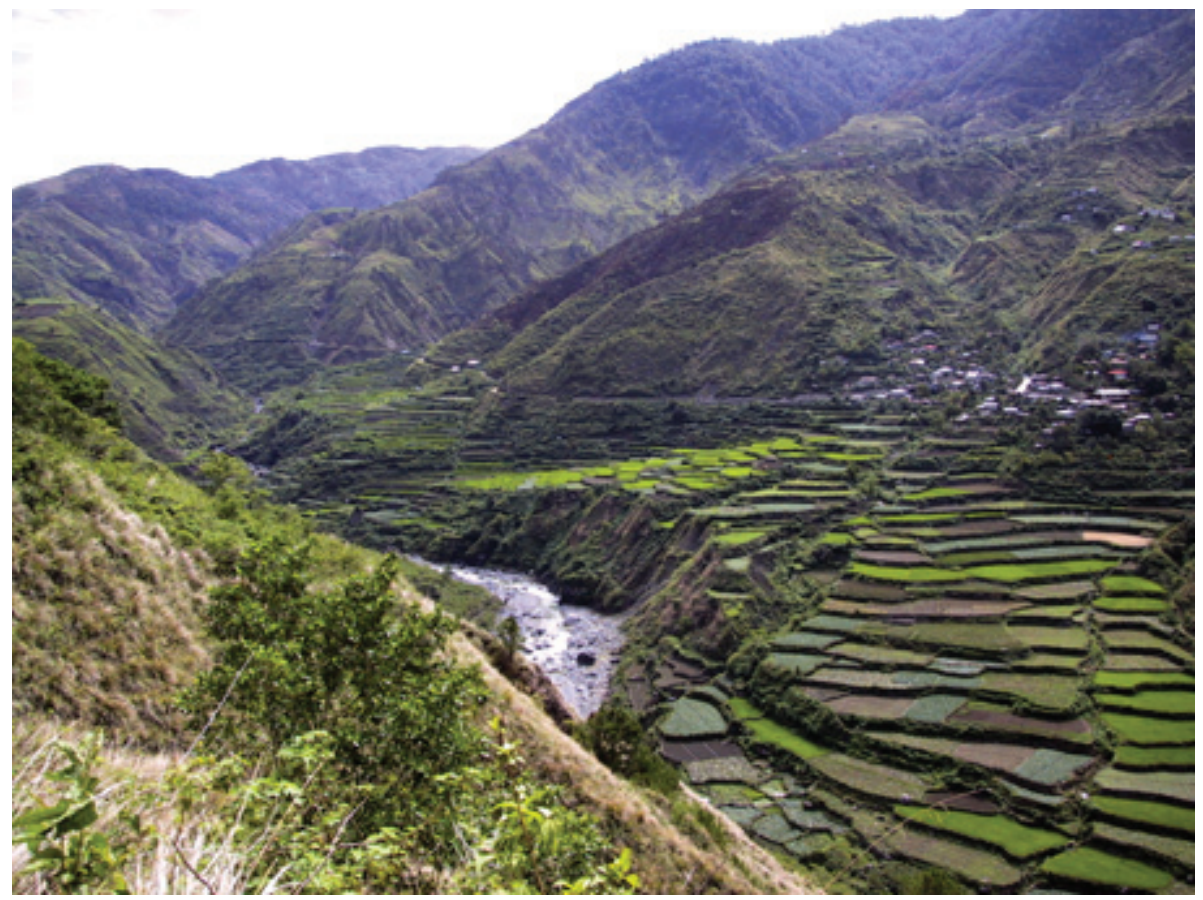

Figure 1. Kabayan region showing terraced farming in the rugged mountain terrain. 


\section{RATIONALE}

Very little information is available regarding the mummification process used by the Ibaloy. However, local oral histories on the tradition of mummification and funerary rituals performed in the region do provide some clues $[8,11]$. We report on recent inspections of the mummified remains made by the authors during two expeditions, one in 2002 and the other in 2012, in an attempt to better understand the mummification process and funerary rituals of the Ibaloy. The research associated with this report was conducted in accordance with the Code of Ethics of the American Anthropological Association [1].

\section{METHODS}

Methods included visual inspection, radiography, endoscopy, ethnography, and radio-carbon dating (RCD). Detailed visual inspection was conducted in both 2002 and 2012 by the authors. In the 2002 expedition, radiography was conducted on-site within the two rockshelters in Mount Timbac using a 1950s vintage Army surplus Picker field X-ray unit. The image receptor used was 8 inch by 10 inch Polaroid instant film within an intensifying screen, which eliminated the need for wet film processing. Video endoscopy was conducted using a 6-mm industrial Olympus videoscope. Image capture was made using the digital video medium. Ethnographic study was conducted in both 2002 and 2012. RCD was conducted on a rib fragment associated with one of the Ibaloy burials located on Mount Timbac, collected during the 2012 expedition. RCD assessment was conducted at the analytical laboratory at the University of Arizona, Tucson, Arizona. Mummies and ethnographic data were respectively inspected and collected on Mount Timbac and Ngalab rockshelters, and in the villages of Kabayan Barrio, Pacso and in Poblacion. Information used in this study was also attained at the National Museum of the Philippines in Manila, as well as the Kabayan Branch of the National Museum.

\section{FINDINGS AND DISCUSSION}

\section{General Observations}

The mummies were placed in wooden coffins of various configurations and entombed high in the mountains surrounding the Kabayan region [16]. The burial locations were typically natural rockshelters or caves that were increased 
in size to accommodate additional coffins. To the Ibaloy, the mountain is the abode of the ancestral spirits (kaapuan) and placing the mummified bodies within the mountain rockshelters or facing the mountain symbolized returning the deceased to Kabunyan, the mountain God.

Unfortunately, many of these tombs have been looted in the past, causing the local municipalities to develop protection methods for the known burials in Kabayan. These methods included locked iron or steel gates placed over the mouth of the shelter as well as placement of a sentry in the location of the burials. One mountain site, Mount Timbac (16’39"3 N, 120'47"43 E), is at 2,715 metres above sea level (8,907 feet). Travel to these remote regions is challenging and can be treacherous due to mud and rock slides. The province of Benguet receives an annual rainfall of $4,500 \mathrm{~mm}$ (177 inches), which can at times cause the burial sites to be inaccessible.

The general bioanthropological features of the mummies studied included mummies of all ages, with both male and female sexes represented. There were large coffins (dungon) representing familial burials. While the oral history supports the family burial construct in both coffin burials and specific family tombs, radiographic evidence supported the concept, seeing inheritable features

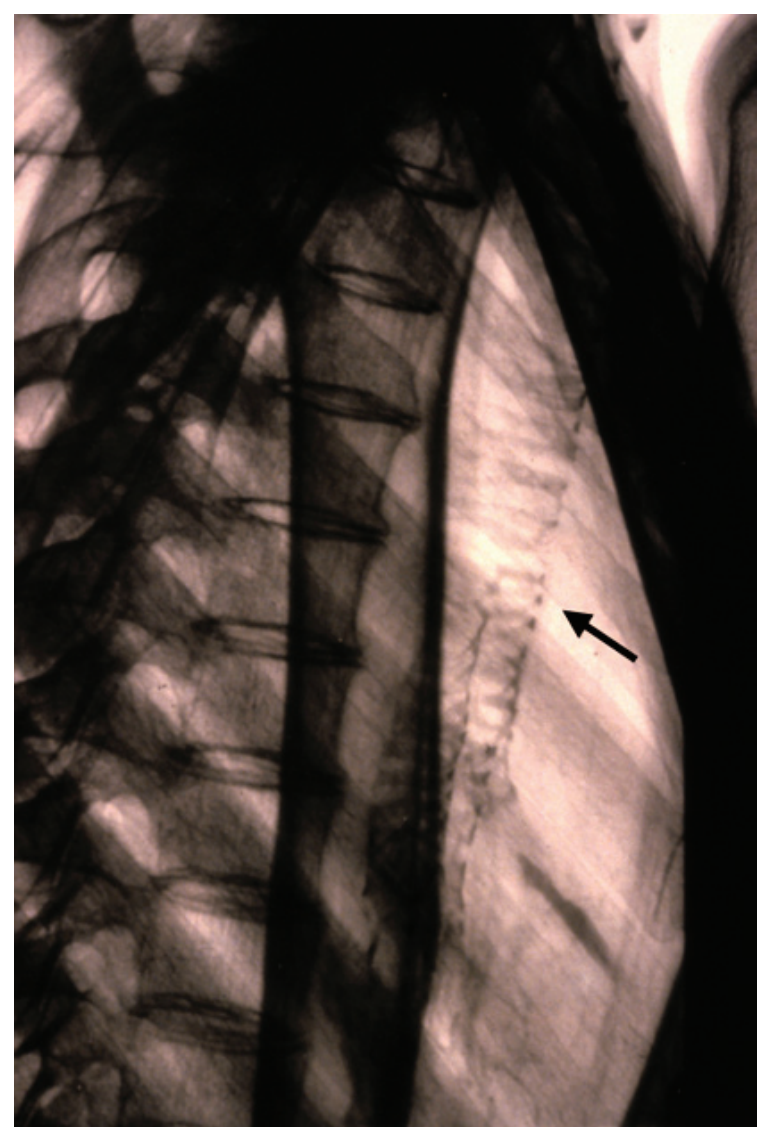

Figure 2. Radiograph showing internal organ structures demonstrating that evisceration was not likely in these mummies. Note the preservation of the tracheal rings within the thorax and the bifurcation of the main stem bronchi (arrow). 
among the large coffin or within shelter burials. Preservation of the internal organs varied from excellent to poor, likely related to the quality of initial mummification procedure, the antiquity of the individual, and the taphonomic changes over time. A number of the mummies presented a hyperextension of the head, which was related to the Ibaloy mummification practices. An adult female mummy at Timbac showed an inverted T-shaped incision on the anterior abdominal wall, which was interpreted as a possible sign of disembowelment [15]. An alternate explanation of the incision derived from oral histories and suggested by local museum personnel was that this particular mummy was subjected to a caesarean section using a sharpened bamboo knife. Local folklore further suggests that if the baby survived, they were fed with the juices from sugar cane. Although enlarged anuses were observed on some subjects suggesting a form of organ removal, evisceration was not evident in these mummies as demonstrated by radiographic analysis (Fig. 2). Many mummies were found to have multiple elaborate tattoos, which will be discussed later in this report. The RCD results from the single rib sample associated with the Timbac burial complex, indicates that it was 185 plus or minus, 43 years BP (1785-1871 AD). Paradoxically, this date is much later than some of the previously reported ones $[14,15]$.

\section{Mummification Method}

According to oral testimony of current Ibaloy from the region regarding the funerary and burial traditions, a reasonable presentation of the mummification method is derived. In addition, radiographic images and visual inspection provide evidence that supports many of the oral claims [9]. The mummification method was complex, apparently beginning at or around the time of death. The first step involved the introduction of a salt solution into the mouth of the deceased or nearly deceased. The individual, once dead, was then washed in cold water. A funerary blanket called kolebao or pinagpagan and a head scarf called sinalibubo were both used to secure the body to the sangachil (death chair). Visual inspection supports the claim that a blanket was used to wrap the individual, as textile impressions can be seen on various parts of the bodies of many of the mummies. The sangachil played an important role in the mummification process. The individual was placed in a seated position on the death chair (i-asal) with his or her head held in position by the aforementioned scarf or band, at times, into a hyper-extended posture (Fig. 3 ). The chair was 
secured to a ladder facing the front of the traditional stilt house. A low fire was lit below and near to the mummy, which likely enhanced dehydration of the corpse. The use of fire in the mummification process caused the Ibaloy mummies to be known as 'the fire mummies'. Body fluids that were expressed or drained through gravity dependence were collected in a jar. Once the dripping had slowed or stopped, the body was removed from the death chair. The body was laid out in the sun and the relatives or elders performed the duduan, the peeling of the epidermis. The body was then treated with juices

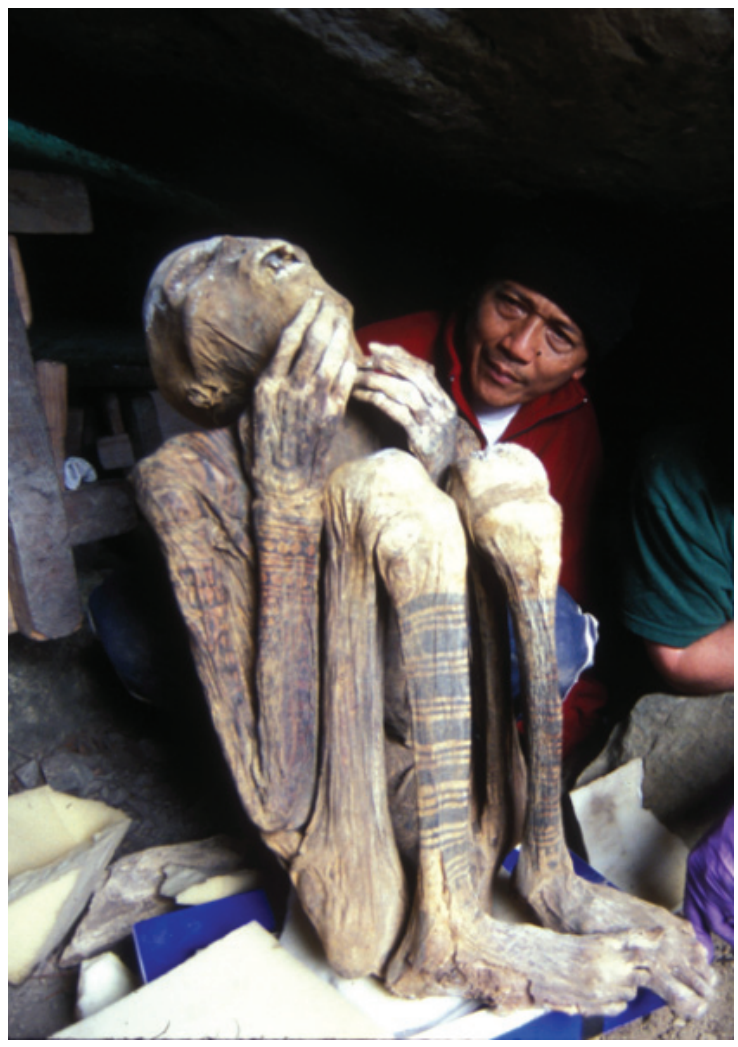

Figure 3. Ibaloy mummy within Timbac rockshelter showing hyperextension of the head associated with the mummy preparation method. from the pounded leaves of local plants, including guava (Psidium guajava), diwdiw (Ficus septica), patani (Phaseolus lunatus), duming (Dolichos lablab), and bisodak/sopidak (Embelia philippinensis) [13]. Additionally, it is believed that the ears and nose were plugged using the leaves of the same plants. Oral reports also suggest that during the process, tobacco smoke was blown into the mouth with the intention to assist the mummification of the internal organs. Although the time required to achieve mummification must have varied depending on many factors, it was suggested that the process required several months of constant tending to the body [15]. Once the process was complete, the body was wrapped with layers of funerary blankets and taken to the mountains for entombment within the appropriate cave [14, 17]. 
While some of the information collected may be anecdotal, such as the use of an expensive substance like salt and the possibility of ingesting the solution prior to death, some features reported in these accounts may, in fact, bring about mummification. The seated position, for instance, may have enhanced desiccation, as the enzyme-laden fluids of the small intestine would have drained out through the perineum [5]. The blanket often used to cover the cadaver may have increased the rate of water evaporation by creating a wicking action. Furthermore, the heat created by the associated fire must have also played a role in the desiccation process, due to the decreased humidity and the greater elevation in temperature [4]. Given that the death chair was placed near the entrance to the traditional house, the fire and associated smoke would have created a microenvironment enhancing the potential for mummification in this otherwise wet environment. Microenvironments such as the use of fire and smoke associated with mummification practices have been demonstrated in other cultures within the tropical forest belt, in particular among the Anga of Papua New Guinea [10]. The smoke from the fire played a major role in the mummification process from a smoke chemistry perspective. The phenolic compounds in the smoke released from the fire would have aided in the preservation of tissues, in that their antioxidant properties would have inhibited decay of fats. Also, their antimicrobial action would have prevented bacterial growth. Additionally, wood smoke often contains formaldehyde and acetic acid which create a hostile environment for bacteria, at the same time encouraging the cross-linking of collagen fibres expelling water from tissues, and, as a consequence, decreasing the enzymatic action which occurs during decomposition. Finally, smoke may have created a physical barrier against insect infestation [10].

On the contrary, some alleged practices must have played a very limited part in the process. The introduction of the salt solution into the mouth seems to have had no impact on organ preservation, as the cessation of peristalsis in a deceased individual would prevent the fluid from traveling beyond the stomach. Similarly, tobacco smoke blown into the mouth would have caused only limited exposure to the internal tissues. Finally, the role of the plant materials employed in the process is not known. There exists the potential that these plant juices create a hostile $\mathrm{pH}$ environment, either acidic or alkaline, for the growth of surface bacteria. In summary, mummification in the Ibaloy tradition was likely achieved primarily from enhanced dehydration accomplished by the heat from the fire, the position in the death chair, the potential 
microenvironment, and wicking body fluids into the death blanket. The forces of decomposition may have further been delayed by the smoke chemistry, increased barrier to insects provided by the smoke, and the plant chemistry. If a salt solution purge was successful, this too may have contributed to enhanced dehydration.

\section{Coffin Styles}

The Ibaloy used various coffin styles to entomb their dead. These coffins are wooden and often carved from hollowed pine trees (Pinus benguetensis) [14]. Not all of the coffins were carved as some were constructed from planks made from similar wood. There are three basic coffin shapes or designs associated with the Ibaloy mummies: ellipsoidal, parallelepiped, or in the shape of a carabao (Bubalus bubalis). Some of the coffins were carved with geometric, anthropomorphic and/or zoomorphic patterns. One zoomorphic pattern observed during the 2012 expedition was that of the snake symbolizing the circle of life and the afterlife. This snake motif symbolism is common to many cultures.

\section{Death Rituals}

The Ibaloy continue to practice and demonstrate various rituals associated with the dead as well as with their interactions with the dead. There is initially a dance (tayaw) and associated prayers or songs that are chanted (bad-iw) for the dead performed by the villagers. In this way, they are communicating their support for the deceased in their journey to the next level of existence. Traditional clothing is worn and the participants are often adorned with a white headband. The symbolism within the dance moves includes a soaring motion as the spirit of the deceased is carried on wings to the mountain. If there is to be a visit to the burial rockshelters, additional rituals are performed to determine if the tombs can be visited. Traditional clothing is worn while the villagers chant or sing a song of welcome. Local red-rice wine is then shared in a wooden bowl. Three forest pigs are sacrificed and their livers and gallbladders are removed. The livers and gallbladders are 'read' by a mambunong (native priest or shaman) to determine if the ancestors approve of a visit to the burial sites. Before traveling to the tomb, other live animals are collected, usually chickens, for rituals to be conducted at the cave entrance. At the burial site, the angba, a song for the mummies and the dead, is chanted. Rice wine is 
shared among the participants as well with the ancestors. At the entrance to the tomb a small amount of wine is offered and poured at the threshold. Typically, the chicken or rooster brought from the village is sacrificed at the rockshelter entrance by hitting or beating the animal with the blood being poured nearby. Food, betel nut, and matches are also offered at the tomb entrance. Once the rituals at the village and the burial site have been completed, the visit with the ancestors can take place.

Generally, there is an entourage of villagers and officials who accompany anyone visiting the burial sites. The intent of the accompaniment is to assure that respect is maintained, and we also suspect that the large group is intended to dissuade would-be thieves. According to custom, it is considered taboo to bring the mummies out of the tomb with the fear of displeasing the spirits of the dead and the resulting trouble that may bring. The mummies could be moved toward the entrance to the tomb but no farther. On occasion, the mummies have come out of the rockshelters for photography but most of the work associated with this research project took place within the tombs (Fig. 4). While collecting data there is someone from the village, often the elder, who is talking to the mummies, explaining who was there and why and explaining any scientific procedures that were being conducted. These various rituals suggest a strong sense of ancestor

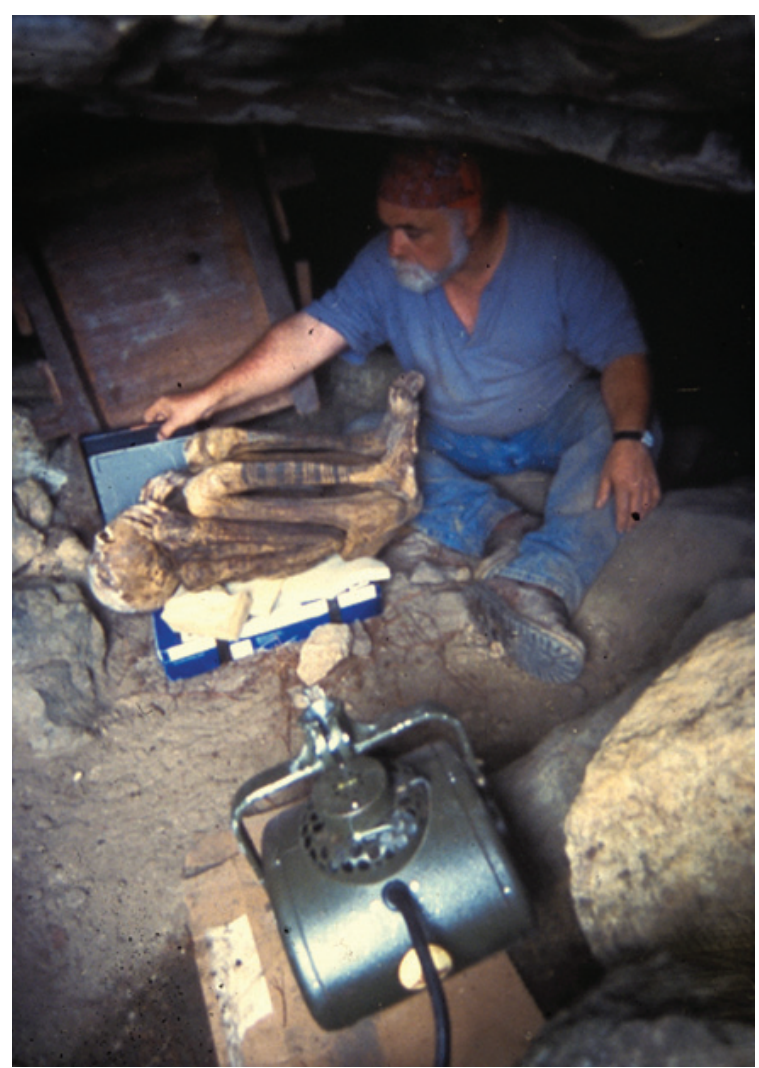

Figure 4. Following local customs of not removing the ancestors from within their rockshelter, here the radiographic study was conducted within a rockshelter at Timbac. 
respect among the living Ibaloy. There is also an apparent attempt to keep the traditions of their culture intact for future generations.

\section{Headhunting}

Ethnographic interviews associated with this study confirmed that the Ibaloy were headhunters in the past. Several individuals spoke of the practice; a 71-year-old man who is currently a shaman among the Ibaloy, a man of 64 years who learned of the practice from his father who was a local priest, and a 78-year-old local, all confirm that headhunting was not uncommon among the Ibaloy. Today, ritualistic headhunts are conducted with heads made from the trunk of a giant fern called tibangdan, carved into the likeness of a human head [18]. The tibangdan is used in the traditional dance ceremony called bendiyan. The false heads are placed at the end of a pole while traditional songs and dances are performed. Today, the bendiyan is regarded by the Ibaloy community as a thanksgiving ritual.

\section{The Practice of Tattooing}

The practice of tattoo adornment is readily apparent among the mummies examined in this study. The Ibaloy mummy tattoos are called batuk or burik. Batuk is a pre-Hispanic practice and was widespread in the $16^{\text {th }}$ century. The batuk served as a visual and material record [19]. There were various purposes for the use of tattoos. They were considered a rite of passage into adulthood and were also seen as bodily adornment. Often the tattoos presented a record of an individual's personal history, a biography of sorts. Other tattoos were intended to be talismans to ward off malevolent forces while others served as marks of bravery. The tattoos were also seen as symbols of status and affluence. Tattooing can be found on all surfaces of the body. The arms, legs, ankles, waist, chest, abdomen, pectorals, and back may all bear tattoos. Even the face, ears chin and eyes may be tattooed yet these locations were reserved for the fiercest warriors of the village. In our study at the Timbac rockshelters, the mummies of adult females were tattooed on the forearms and upper arms while the adult male mummies had whole body tattoos including the fingertips. Additionally, there were unfinished tattoos as well.

The designs associated with the tattoos were varied. Typically, there were geometric figures depicting lines, circles, triangles, chevrons, and others. There were also figurative tattoos including human figures, deer, centipedes, snakes, 
lizards, the sun, and plant forms. Mountains, lightning, and water were also common designs. Many of the symbols used in tattooing held specific significance. Generally tattooing was thought to assure a long life and serve as individualistic ornamentation. Tattooing was also believed to have the power to cure and ward off such maladies as smallpox. The main motif indicated a selfsense as prime element within the context of the individual's existence and reality. The snake motif indicated a belief in the spirit, the soul, and life after death.

The tattoos were created by a tattoo practitioner called a manbatok. This individual may have been a local resident or one who travelled from village to village. The first step of the process was to make a puncture with a thorn from a local plant called maguey (Furcraea foetida). Other reports suggest the use of the thorn of citrus trees. Next the thorn was dipped into an 'ink', a slurry made from ash and crushed native tomato plant leaves. The desired pattern was then produced on the skin. An alternate description conveyed to us during our ethnographic interviews was that the pattern was first made on the skin using the thorn. Then the 'ink' was spread across the puncture sites with the excess being washed away leaving the design. The 'ink' served as both the colouring agent as well as a healing solution at the puncture sites. The resulting colour was a bluish or greenish black hue presenting as the intended design. The process was labour-intensive and very painful. Tattooing a single arm could take an entire day, while a whole body could take months or years depending on the pain tolerance of the individual. The practice of traditional tattooing continues in other parts of the Cordillera region, specifically in Kalinga, while it waned among the Ibaloy communities in Benguet [20]. The decrease in the tattooing tradition is due in part to the loss of artisans and due to a decline in the significance of tattoos brought on by Christianity and education. Today, contemporary tattoo artists render these traditional tattoo patterns as seen on the mummified ancestors [19].

\section{Current Attitudes toward the Mummified Ancestors}

During our study, we were able to interview several individuals willing to discuss their current beliefs regarding the mummified ancestors and their relationship to the mummified dead. Baban Berong (1922-2005) was the village elder during our 2002 expedition to the Kabayan region. Berong explained that their belief is that God is a mountain and the burials are either within these mountains or facing sacred mountains. The mummy is sacred and contains the 
soul, according to Berong. The belief is that the spirit of the individual remains with the body, and therefore the mummified remains must be treated with utmost respect. The village and burial rituals experienced, as well as keeping the mummies within the tombs, are representative of this respect. The Ibaloy of Kabayan speak to the mummies as if living and we, as researchers, were introduced to the mummies as if they were living. While Baban Berong holds the more traditional view of the relationship of the Ibaloy to their mummified ancestors, others within the community hold dichotomous views. A 45-year-old man of the village of Poblacion believes that the spirit of the mummies exists and that these spirits are responsible for periodic calamities when they are displeased with the living for some reason. In contrast, a 79-year-old weaver of Gusaran believes that the old ways are a dead tradition. The weaver feels that if there is a calamity, it has nothing to do with the mummies or their spirits. Given the opposing views regarding the mummified ancestors and their spirits, we found it interesting that, although there is a cemetery in the villages, the villagers tend not to use it. A 50-year-old female informant of Poblacion explains that most rather inter their deceased loved ones in a garden of their homes in soil graves or tombs. This current practice suggests that the sense of spirit of the deceased may actually still exist, as they prefer to have their loved ones close by. An alternate explanation may be that the surviving family members do not want the bodies of their loved ones stolen, as has been the case with many mummies from the region [12].

Ana Labrador, a social anthropologist who is also the assistant director of the National Museum at Manila, offered some interesting impressions of the Ibaloy culture with respect to the mummification rituals (personal communication, 2012). Labrador suggests that the Ibaloy see life as a transition, as they prepare for another life beyond death. The tightly flexed mummies resemble the foetal position and this is seen as a return to the beginning. This correlates well with Baban Berong's sense that the God is a mountain and that the mummies are being returned to where they came from, the mountain. Labrador brings out another important idea as well in that the mummies have become a symbol of regional identity. Mummy tourism helps the community by providing jobs and income. However, there are always trade-offs in that while mummy tourism may be fiscally beneficial, the trails and the mummies themselves are showing signs of deterioration beyond the effects of climate change and natural disasters. 


\section{CONCLUSIONS}

The intent of this project was to investigate historical sources and collect bioanthropological information in situ in an attempt to better understand the mummification process and funerary rituals of the Ibaloy. Additionally, our aim was to examine significant ethnographic accounts of this mortuary behaviour. The data collected resulted from two expeditions conducted by the authors. As with many such practices, it is becoming increasingly more challenging for the Ibaloy to keep the traditions alive. Thus, the results and subsequent reporting of these research findings not only enhance our understanding of these unique mummification and burial practices, but also serve to record the information for future researchers to build on.

\section{ACKNOWLEDGMENTS}

The Local Government Unit of Kabayan, Benguet; The National Museum of the Philippines, Kabayan Branch, Benguet; The Bioanthropology Research Institute, Quinnipiac University, Hamden, Connecticut; The Mummy Road Show, The National Geographic Channel, Washington, DC; The National Geographic Society, Washington, DC; Alexis Duclos and Nancy Ing; Gea Guerriero, PhD; Dong Hoon Shin, PhD.

\section{REFERENCES}

1. American Anthropological Association (2009). Code of Ethics. Retrieved July 2015, archived by WebCite at http://www.webcitation.org/6Zhe6YBvC.

2. Anonymous (1985). Kabayan '85. A socio-economic profile. Kabayan.

3. Anonymous (2003). Comprehensive Land Use Plan, Kabayan, Benguet - 20032012, prepared by: The Municipality CLUP - MTWG of Kabayan. Benguet. part I and II.

4. Aufderheide A.C., Aufderheide M.L. (1991). Taphonomy of Spontaneous ("Natural") Mummification with Applications to the Mummies of Venzone, Italy. In: Ortner D.J., Aufderheide A.C. (eds) Human Paleopathology: Current Syntheses and Future Options. Smithsonian Institution. Washington DC. 79-86.

5. Aufderheide A.C. (2003). The Scientific Study of Mummies. Cambridge University Press. Cambridge.

6. Bagamaspad A., Pawid Z. (1985). A People's History of Benguet Province. Baguio Printing and Publishing. Baguio City. 
7. Ballard L., Afable P. (2011). Ibaloy: Dictionary, Phonology, Grammar, Morphonemics and History. Dinteg Inc. and the Cordillera Studies Center, University of the Philippines Baguio. Baguio City.

8. Baucas B.L. (2003). Traditional beliefs and cultural practices in Benguet. New Baguio Offset Press. La Trinidad.

9. Beckett R.G., Conlogue G.J. (2010). Paleoimaging: Field Applications for Cultural Remains and Artifacts. CRC Press. Boca Raton.

10. Beckett R.G., Lohmann U., Bernstein J. (2011). A Field Report on the Mummification Practices of the Anga of Koke Village, Central Highlands, Papua New Guinea. Yrbk Mummy Studies, 1, 11-17.

11. Cardin M. (2014). Mummies around the world. An encyclopedia of mummies in history, religion, and popular culture. ABC Clio. Santa Barbara.

12. De Leon L. (1976). The mummies of Benguet. Philippine Panorama, August 8.

13. Madulid D.A. (2001). A Dictionary of Philippine Plant Names. 2 Volumes. Bookmark. Makati City.

14. Merino F.S. (1989). The Kabayan Mummies and the Bendiyan Canao. The Author. Kabayan.

15. Morimoto I. (1993). Mummies of the Ibaloi (Benguet-Igorot), Luzon, Philippines. In: Group for Research of Japanese Mummies (ed.) Worship of Mummies in Japan and China. Heibonsha Limited Publishers. Tokyo. 369-407.

16. Panganiban M.B., Omana L.T. (1998). Geological and Geomorphological Perspectives of Mummy Caves of Kabayan, Benguet. National Museum Papers 8, $2,1-22$.

17. Picpican I. (2003). The Igorot Mummies. A Socio-Cultural and Historical Treatise. Rex Book Store. Quezon City.

18. Pungayan E.L. (1985). The Bendian: an Unsavored Reminder of a Buried Ibaloi Past. Saint Louis Research Journal, 16, 1, 90-111.

19. Salvador-Amores A. (2012). The Recontextualization of Burik (traditional tattoos) of Kabayan mummies of Benguet to contemporary practices. Humanities Diliman, 9, 1, 55-94.

20. Salvador-Amores A. (2013). Tapping Ink, Tattooing Identities: Tradition and Modernity in Contemporary Kalinga Society. University of the Philippines Press and the Cordillera Studies Center, University of the Philippines Baguio. Quezon City.

\section{Address for correspondence:}

Dr Dario Piombino-Mascali

Anatomicum

M.K. Čiurlionis Street 21, 03101 Vilnius, Lithuania

E-mail: dario.piombino@mf.vu.lt 